\title{
CONCEPTUALIZING THE PRINCIPLES OF SOCIAL MEDIA ENGAGEMENT: TEACHINGS FROM SELECTED VERSES OF SURAH AL-HUJURAAT
}

\author{
Muhammad Maga Sule ${ }^{1}$ and Atiku Garba Yahaya ${ }^{2}$ \\ ${ }^{1}$ Department of Islamic Studies, Usmanu Danfodiyo University, Sokoto. \\ ${ }^{2}$ Professor, Department of Islamic Studies, Usmanu Danfodiyo University, Sokoto. \\ Email: mohammed.maga@yahoo.com
}

\begin{abstract}
$T$ he speedy advancement in internet technology has revolutionized the use of social media platforms as ways of communication globally. This paper examines the proliferations social media sites in the world and its use among the Muslims. Unlike traditional media, most of internet based means of social interactions are user-generated. It allows the individual to determine the content of the message with or without censorship or regulation. The liberty to open an account with any site of choice and the freedom it entails, lured some Muslims to surf social media without recourse to or in line with the basic tenets of Islamic teachings. The paper is a qualitative method where In-Depth Interviews were conducted with seasoned social users. The researchers purposively selected three participants for the study and interview because they are Muslims and possessed the knowledge about the phenomenon investigated. Some of the findings of the study revealed that some Muslims finds it convenient to share or post unsubstantiated religious messages on social media. Similarly, it has paved way for increasing number of untrained social media preachers. This makes it a delicate tool at the disposal of some of Muslim to fan antagonism among Muslim of creeds and sects in Nigeria. The article concludes that social media is a double-edged sword which side-effects as apparent when Muslim user do not resort to the teachings of Islam as the guiding principle when surfing the social media sites. The unfettered user-generated content of social media in $21^{\text {st }}$ century enables the users to operate outside the ambit of the Islamic convention of social interactions.
\end{abstract}

Keywords: Social Media, Principles, Engagement, Social Interactionns, Islamic Teachings 


\begin{abstract}
ABSTRAK
$\mathrm{K}$

emajuan cepat dalam teknologi internet telah merevolusi penggunaan platform media sosial sebagai cara komunikasi global. Makalah ini meneliti proliferasi situs media tradisional, sebagian besar sarana interaksi sosial berbasis internet dihasilkan oleh pengguna. Hal ini memungkinkan individu untuk menentukan konten pesan dengan atau tanpa sensor atau regulasi. Kebebasan untuk membuka akun dengan situs pilihan apa pun dan kebebasan yang dimilikinya, memikat sebagian Muslim untuk berselancar di media sosial tanpa bantuan atau sejalan dengan prinsip dasar ajaran Islam. Makalah ini mengadopsi metode kualitatif pengumpulan data melalui wawancara mendalam dilakukan dengan pengguna medsos berpengalaman. Peneliti secara sengaja memilih tiga peserta untuk studi dan wawancara karena mereka adalah Muslim dan memiliki pengetahuan tentang fenomena yang diselidiki. Beberapa temuan penelitian ini mengungkapkan bahwa beberapa muslim merasa nyaman untuk berbagi atau memposting pesan agama yang tidak berdasar di media sosial. Demikian pula, ini telah membuka jalan untuk meningkatkan jumlah pengkhotbah media sosial yang tidak terlatih. Ini membuatnya menjadi alat yang halus yang bisa digunakan oleh beberapa muslim untuk mengipasi antagonisme di antara muslim dari kepercayaan dan sekte di Nigeria. Artikel ini menyimpulkan bahwa media sosial adalah pedang bermata dua yang efek sampingnya tampak jelas ketika pengguna muslim tidak menggunakan ajaran Islam sebagai prinsip penuntun ketika menjelajahi situs media sosial. Konten yang dihasilkan pengguna dari media sosial di abad ke-21 memungkinkan pengguna untuk beroperasi di luar wilayah konvensi Islam tentang interaksi sosial.
\end{abstract}

\title{
Kata Kunci: Media Sosial, Prinsip, Keterlibatan, Interaksi Sosial, Ajaran Islam
}




\section{INTRODUCTION}

The current development of information technology and Internet services has relieved many things in the contemporary world and most people's lives and activities are significantly influenced by it. In the same manner, social media platforms are continuously creating a significant impact on the whole world, it is not only having negative impacts which have hit the socio-economic and cultural settings, but it also patterns the religious lives of the people. Despite the positive development achieved in the use of the social media by religion (i.e. Islam) there are grounds on which its use is threatening the true teachings of Islam. It is still a threat to Islam as a complete religion and a way of life to mankind which is all encompassing in its coverage of human life. Any deed carried out by humankind on earth should be geared towards worshipping Almighty Allah alone or doing something which is halal and in accordance with the provisions of the sources of Islamic law (Shari'ah). However, only true Muslim believers strive with their wealth and lives for the cause of Allah and observe what is commanded by Allah. Although social media has come with its own evils which are un-Islamic, it is still important and useful to Islam and Muslims within the principles of halal (permitted) and haram (prohibited). It is in the light of this that this article examined the social media in the light of selected verses of the Glorious Qur'an.

Access to and usage of the internet, and especially the social media, is vital to many people around the globe, particularly the youth. Thus, there exists a compound interface and dependence of humankind today on information technology and particularly the social media. There is a geometric increase in the subscription all over the world, by the youth, and this is largely because the social media facilitates easy, quick, global access to unlimited information to all. Information technology and its package (the social media) is, consciously and otherwise significantly changing the pattern by which people relate, think, practice their religion, conduct business, politics and all other things in life and in both positive and negative ways. Hence, the influence and change on individuals' behaviour (Packard, 2013). It has been observed by Baran (2013), that four (4) freedoms are generally associated with the internet and precisely, the social media. These are freedom of access to contents; freedom and usage of available applications; freedom to attach devices; and freedom to obtain service plan information. These social media platforms can be used for halal or haram (i.e. it can be used for good or bad). There are people who used these platforms for immorality, they used it for Zinah, cheating, slander, backbiting and scam. Some use it to stay connected to their families and friends around the globe, while some use it for the propagation of religious, and promotion of products.

The aim of this paper is to identify the utilization of social media by Muslims whether it is in accord with the Islamic teachings. In order to achieve the aim, this paper proposes a framework;

i. To identify the application of Islamic teachings in the use of social media platforms by Muslims.

ii. To evaluate the abuse of the teachings of the verses of the Glorious Qur'an as it relate to social media usage by Muslims. 
iii. To evaluate the effective ways of using social media platforms in accordance with the teachings of Islam.

\section{Theorizing Social Media}

In today's digital age, the social media platforms are more than just means of seeking information only. The rapid development in internet technology has turned the social media platforms into innovative ways for people to communicate with others. Mujib (2014), asserted that social media platforms can be viewed as packages based on the internet that allow individuals to connect with the other persons by sharing, communicating and connecting within the system while allowing people to design their profiles within a controlled network. Usually, people use social media platforms like Facebook, WhatsApp, Twitter and MySpace to build and keep up relationships with others (Boyd \& Ellison, 2007). The special feature of social media platforms' functions enable people to communicate with others across distance, as it also allow people to share information such as image, video, and conduct conversations in real time. The social sites have thus become trendy to today's young generation. The popularity of social network has attracted numerous groups of people especially higher education students. Muslims might use this platform to simplify learning session with friends and for other academic activities since it offers interactive communication either on-site or off-site. However, according to Islamic injunction, a Muslim has to follow several guidelines in using social media platforms especially for making friends between different genders. In addition, as a Muslim, it is prohibited in sharing any inappropriate contents that contain document, video, musical and song anonymously; that is materials which sources are not acknowledged or attributed. Harvey (2014) has identified six (6) types of social media platforms as Wikipedia, Blogs and microblogs (Twitter), content communities (YouTube), social networking sites (such as Facebook), virtual game worlds, and social worlds. He further admitted that social media are changing the way people live and communicate with others and at the same time making it easy for the international technology of social networks to operate at a speedier, dependable and cheaper cost. Indeed, the way and manner in which people communicate, consume media and seek and receive information is changing through the social media which is reliant on cultural geography. It thus does not have any single definition, but it is determined by the number of those who retrieve what is sent by and who the sender(s) are as noted by (Harvey, 2014). He also added that the social media has evolved into a crucial resource for obtaining large volumes of real-time information. It is generally characterized as technically structured; personal; on daily increase, and according to importance to subscribers and issues at hand, prone to general and specific maneuver; dealing with small messages, straight and usually personal; fast dissemination; instant and unplanned in expression of beliefs, experience and observations as well as entertaining but unsafe. Mostly, access to internet resources facilitate enrolment into educational institutions, job acquisition, interpersonal communication with social groups and colleagues, conduct of research, marketing and purchasing, and dissemination of information on health and other matters. 
Muhammad Maga Sule and Atiku Garba Yahaya

While inaccessibility to or non-use of the social media may result in social isolation of individuals (Hindman, 2000; Hammond, 1997).

The internet and its packages provide instant access to all forms of media violence as the web provides unregulated audiovisuals, games and writings (Eastin, 2013). Specifically, the new social media involves contradictory forces, offers tempting opportunities and poses new threats, for it does not distinguish between true and false, biased and objective, trivial or important (Baran, 2013). It has, in addition, substantially facilitated and increased 'social capital' (especially among the younger ages, religions) which, according to Hawe \& Shiell, (2000) and Veenstra (2000) refers to the use and benefits derived through participation in networks and other socially driven structures. There is however, a growing worry all over the world on the vices of the social media, especially pornography among children and young adults, which are largely and easily accessed from every reach (Smith \& Bird, 2002). Theocharis (2011) has lamented that the internet and social media have brought 'postmaterialism' which depicts not only solidarity, creativity and free expression, but also declining respect for constituted authorities, especially among young individuals. Islam and Social Media

Social media has become a hot topic of debate through its role and effectiveness in creating awareness and giving the sense of motivation among its users on various social, political, economic and religious issues. Social network sites are communication nodes, which ties between individuals, groups, organizations, and related systems with different types of interdependencies. It has included shared values, visions, ideas and group participation events, among numerous other aspects of human relationships (Serrat, 2009). These sites allow individuals to present to others using different formats, including text and video (Hernandez, 2010), allowing individuals to get a visible list of connections with others (Coyle, et al., 2008).

Islam is a comprehensive religion, it has both spiritual and temporal life as there is no matter that it has not been covered, contained or accommodated by it. In describing Islam, Moten (1984) stated that Islam is not a common conventional religion with metaphysical doctrines and rituals, but rather, a complete and comprehensive way which embraces all the dimensions of human thoughts, actions, spiritual, and mundane life. Muslims are made self-sufficient and raised high above all others (The Glorious Qur'an, Chapter 6: 38 and Sahihul Bukhari, Volume 9. Hadith No.376). As a result, everything in this world and hereafter has been completely envisaged by Islam and the ways to do and undo things are clearly provided through the Shari'ah. For the Glorious Qur'an and Prophetic Hadith, the provisions are emphatically made with categorical and empirical references. For those things which changing times (dynamism, development and advancement) may come with, Islam is also dynamic in the sense that it has already envisaged and contained all such that may come with changing times. Social media has transformed means and manners of social interactions, which includes relating with members of religions and cultures, and the promotion of radical thoughts and views, notions and morals (Halverson, 2012). One of the main vices associated with the social media are the posting, sharing and forwarding of contents 
for or against the benefit of the society. According to Cheong (2011), social media practices can deepen spirituality. However, "there are concerns about the role of social media in fraying religious ties as individuals choose to consume online religious experiences and withdraw from houses of worship. Although there are concerns from religious leaders that religious activity on social media will replace traditional in-person attendance at places of worship, little research has been done to prove it.

Similarly, social media are tools for invigorating the ethos of Islam in terms of its political virtues, moral value, and spiritual principles. In contemporary period, social media have become the most vital tool in projecting ideas of Islam to every nooks and crannies of the society. It is imperative to note that if we are desirous of blending with this modern trend, we must develop our concept and agenda to guide the Muslims in the appropriate and legitimate ways of using social media facilities (Abu Sulayman, 2016). Consequently, if we sit back and watch, then the rest of the world will move on while we remain static. We should in earnest make use of Facebook, Twitter, My Space, WhatsApp, Blackberry messenger etc. in promoting, projecting and disseminating the teachings of Islam among Muslim students and students of other faiths (Zakir, 2016).

Related to this, social media applications are relatively economical ways to afford the people who would not normally have the courage to ask questions about Islam or to see the inside of a mosque, the opportunity to look inside. With all the advantages of social media, it is taking up a lot of our time and affecting other aspects of our lives. On the average, we may be spending 2-3 hours a day on social media, without realizing how much time we are spending on our mobile phones, iPads, and computer screens (Javeria, 2011).

Privacy has also been of main concern in mass communication and also to the persons (Bahrain, 2013) thus Packard, (2013) has decried the misuse of rights to privacy over the social media which results in disturbing pain as a result of the invasion of the private lives and affairs of people through disclosure of their personal secrets and information. Perritt (1996) has in the same vein, noted what he called invasion of privacy' by the publication of personal information, giving bad names, images and tagging people with offensive names and spreading lies which have been part of human interaction and enjoying greater reach (Baran, 2013). This is because in Islam, even where others have said or done an evil act, a Muslim is not expected to publicise such evil information/act onto others.

\section{METHODOLOGY}

This paper is a survey type which adopted qualitative techniques to elicit primary data from the participants. The population for the study were civil servants and a student. To elicit the data, the researchers conducted In-Depth Interview (IDI) and non-participant observation. The paper adopted purposive sampling technique to select the participants for the interviews and observations, this has enabled the researchers to select participant who possess in-depth knowledge about the phenomenon investigated. This is because the aim of qualitative study is not to cover large sample but to study select few participants and examine the phenomenon 
Muhammad Maga Sule and Atiku Garba Yahaya

deeply. The researchers purposively selected three participants where three InDepth Interviews (IDI) were conducted. The researchers with the used of observation checklist, observed posts and comments of some Muslims on Facebook and WhatsApp for three months. The elicited from the participants were transcribed verbatim, coded and analyzed based on theme study. Similarly, data collated from the observations were integrated with the data generated from the interviews.

\section{RESULTS AND DISCUSSION \\ General Overview of the Teachings of Suratul Hujuraat}

This Surah is a Madinan Surah and takes its name from the reference to Prophet's (Sallallahu Alayhi Wasallam) private apartments in verse 4 . The subject matter of the Surah is to teach Muslims the manners worthy of true believers. The Surah deals with social aspects of Muslim society, enlightening the believers on how to interact with the Prophet Muhammad (Sallallahu Alayhi Wasallam) with due propriety, and with each other with mutual respect and trust. The concluding passages point out the differences between true faith and a mere outward adherence to religious practice. The chapter begins by stating that Allah knows all and hears all, and ends by stating that Allah knows the unseen and sees all, this being a theme of the whole chapter and hence the recurring counsel is to be mindful of Him.

The Surah comprises 18 verses and 343 words. It has no verses that were later abrogated. It was revealed after $\mathrm{Al}$ Mujadilah and before Al-Tahrim, making it the $108^{\text {th }}$ Surah revealed to Prophet Muhammad (Sallallahu Alayhi Wasallam).
It was revealed in the $9^{\text {th }}$ year after the Hijra when a large number of persons were embracing Islam, and many delegations were also coming to visit Madinah to meet the Prophet (Sallallahu Alayhi Wasallam) and to learn about Islam.

\section{Social Media as it Relates to Verses 6, 10, 11, 12 and Verse 13 of Surah Al-Hujuraat of the Glorious Qur'an}

This Surah is central to this research because it provides solution to the social problems of the Muslim Ummah including the problems the Ummah are facing when it comes to social media. In this surah, five (5) verses of the surah are central to the research. These verses are verses $6,10,11$, 12 and 13. And Muslims need to apply these verses when it comes to social media. Today in an era of Information and Communication Technology, information can be passed without difficulty to communities and without verification of the contents. Plenty of messages that are circulated are really false. Things can get even worse when information is passed around about other people, causing rifts in families and a lot of pain and hurt (Raiiq Ridwan, n.d.). Caliph Umar bin A1-Hattãb, (may Allah be pleased with him) said,

It is sufficient lie for a man to speak of everything that he hears (Hadith in Muqaddimah Sahih Muslim).

Narrating whatever we hear is considered lying, and Allah has cursed the liars over 10 times in the Qur'an. It is something that Muslims definitely need to stay away from as Allah says; 
Conceptualizing The Principles Of Social...hal.1-18

Woe to every sinful liar
(Qur'an, Surah Al-Jaathiya
45:7).

As Muslims, there is need to verify every single message that come our way, whether it is true or not, be it news about global politics, information on business, fatwa and or information about someone's reputation, one needs to verify the information before sharing or posting such in the social media. And if one is very lazy to verify the content he/she wants to share or forward, then he/she should be very lazy to share and forward that content online.

People always receive messages on the social media about certain products like (chocolate, biscuit beverage etc.) and that such products are harmful and deadly, so the product should not be consumed, and without confirmation people keep sharing and forwarding such information. Many Muslims are unfortunately engaged in this type of acts. This have ruined a large number of businesses. Almighty Allah says in the Glorious Qur'an in Surah AlHujuraat verse 6;

O you who have believed, if
there comes to you a
disobedient one with
information, investigate, lest
you harm a people out of
ignorance and become, over
what you have done, regretful
(Qur'an, Surah Al-Hujuraat 49:
Verse 6).

There are a lot of breaking news today repeatedly on the social media of unverified information. And people do share and forward these contents, without verification, either through WhatsApp, Facebook, Twitter, Instagram and other social media sites. It has been observed that many times people post and share contents online without verifying such contents. Unverified Ahadith of Prophet Muhammad (Sallallahu Alayhi Wasallam) are being posted and shared on the social media. This unverified Ahadith could be taken from sources which were against Islam and Muslims, which could mislead Muslims who are not knowledgeable about the true teachings of Islam.

There are many WhatsApp, Facebook and Twitter messages going round that are full of fabricated Ahadith often wrongly attributed to the Prophet Muhammad (Sallallahu Alayhi Wasallam). Sharing of fabricated Hadith and ascribing it to Prophet Muhammad (Sallallahu Alayhi Wasallam) amounts to lying against him. It has been stated categorically that lying against the person of Prophet Muhammad (Sallallahu Alayhi Wasallam) is a sin. Therefore one must verify the Hadith before forwarding it or do not at all. Prophet Muhammad (Sallallahu Alayhi Wasallam) says;

It was narrated that Abü Hurairah said: "The Messenger of Allah (Sallallahu Alayhi Wasallam) said: 'Whoever tells a lie about me deliberately, let him take his seat in the Fire." (Sahih Muslim, Hadith No. 4, Chapter 2).

Under this also, unconfirmed and misleading information have led many persons to lose their lives and others were hospitalized in Nigeria during the outbreak of Ebola Virus. On $7^{\text {th }}$ August 2014, a female student from the Federal University of Technology Akure, Ondo State, Nigeria, by name Adesewa, sent a message to her 
Muhammad Maga Sule and Atiku Garba Yahaya

friend via Blackberry Messenger (BBM) that the Ministry of Health had asked everyone to bathe with hot water and salt and also drink same as it is a prevention against Ebola Virus. Adesewa's message quickly spread on other social media platforms and was so disastrous in the country due to lack of authentication of the genuineness of information and its source. This is why the Glorious Qur'an strongly advises Muslims to always verify any piece of information that comes their way as some news are but the imagination of the person who spread such messages. In Myanmar, as a consequence of the lack of information authentication and verification, the Facebook was used to spread rumours and hate speech against the Rohingya Muslims who were dominant in the Rakhine province, where most Rohingyas lived. This led to violent attacks against them. In August 2017, 6,500 Rohingyas were killed and many more displaced in what the United Nations described as a systematic attack on the civilian population. Consequently, the United Nations called for senior military leaders to be tried for war crimes

(http://ploughshares.ca.pl publications/soci al-media-and-conflict/.). This is how spreading whatever comes our way on the social media, as it is the fastest means of communication today, may lead to the destruction of the lives and properties of innocent person around the world.

\section{Verse10: A Reconciliation between the Warring Parties}

In general, the essence of the relationship between mankind and Allah and the relationship between fellow human being involves communication. Through the relationship between mankind and Allah, communication was conducted through Ibadah and Taqwa. Muslims are to always make peace and reconciliation between their fellow Muslim brothers whenever they discover that there is a dispute among online (social media). Meanwhile, as for the relationship between a man and other man was performed based on Akhlaq and brotherhood as stated in the Glorious AlQur'an;

The believers are but brothers, so make settlement between your brothers. And fear Allah that you may receive mercy (Qur'an, Surah Al-Hujuraat 49: Verse 10).

It has been observed by the researchers that Muslims on the social media are always fighting one another and breaking the bond of brotherhood which Islam has established between Muslims as stated in verse 10 . It has been observed by the researchers that when one goes through most of the posts and comments by Muslims on the social media, it is mostly derogatory comments against each other, against Allah's call on Muslims to be brothers to each other. In some instances, on the social media, due to rivalry, a Muslim will make photo-shop of a fellow Muslim scholar either naked or hugging a woman just to portray him as a fasiq. All these are done merely because they do not share the same opinions over certain aspects of the religion with the scholar. This then triggers a chain of reactions, in like manner, from the followers of the injured scholar. Such exchanges of dubious claims are against the teachings of Islam. When someone shared a fatwa from their favaourite scholar on Facebook and if such fatwa does not suit the interest of other 
fellow Muslims, they resort to naming calling, and even declaring persons who do not share in their fatwa as kafr. A fight soon ensues on the comment section with ugly replies to each other via the social media. Islam is against calling a fellow Muslim brother an infidel. The Noble Prophet (Sallallahu Alayhi Wasallam) says;

Ibn 'Umar (May Allah be
pleased with them) said: The
Messenger of Allah
(Sallallahu Alayhi
Wasallam) says, "When a
person calls his brother (in
Islam) a disbeliever, one of
them will certainly deserve
the title. If the addressee is
so as he has asserted, the
disbelief of the man is
confirmed, but if it is untrue,
then it will revert to him."
(Riyad Us-Salihin, Book 18,
Hadith 1732).

He also said,

Abu Dharr (May Allah be pleased with him) reported: I heard the Messenger of Allah (Sallallahu Alayhi Wasallam) saying, "When any Muslim accuses another Muslim of $\sin$ or of disbelief, the reproach rebounds upon the one who utters it, if the other person is not deserving of it" (Riyad Us-Salihin, Book 18, Hadith 1560).

It was also narrated that the Prophet (Sallallahu Alayhi Wasallam) said,

\begin{abstract}
Abu Hurairah (May Allah be pleased with him) said: The Messenger of Allah (PBUH) said, "When two persons indulge in abusing each other, the beginner will be the sinner so long as the oppressed does not transgress the limits" (Riyad Us-Salihin, Book 18, Hadith 1561).
\end{abstract}

Some Muslims are fond of casting aspersion on their leaders on social media most especially if that leader is a Muslim with the intention of tarnishing his reputation just because of political or mere sectarian difference which hardly can be found among the adherent of other religions. It is very difficult for the followers of religion other than Islam to criticize their leaders on the social media. But some Muslims find it fashionable to insult or cast aspersion on their leaders be they political or religious leaders via the social media. While Almighty Allah has already told us that Muslims are brothers to one other. Added to it, Islam has laid down means of correcting a fellow Muslim if he is going the wrong path. Insulting or trying to tarnish the integrity of a Muslim on social media will not make him change for good but rather it will make him worst. Allah says,
The believers are but brothers, so make settlement between your brothers. And fear Allah that you may receive mercy (Qur'an, Surah Al-Hujuraat 49: Verse 10).

And the Prophet (Sallallahu Alayhi Wasallam) says in one of his Ahadith that 
Muhammad Maga Sule and Atiku Garba Yahaya

the Muslim is a brother to a fellow Muslim. Narrated Abdullah ibn Umar, that the Prophet (Sallallahu Alayhi Wasallam) says,

The Muslim is the brother of his fellow Muslim; he does not wrong him or let him down. The one who meets the needs of his brother, Allah will meet his needs. Whoever relieves a Muslim of distress, Allah will relieve him of distress on the Day of Resurrection (Sahih Muslim Hadith 2580).

\section{Verse 11: Mockery Defamation, and Ridiculing}

In verse eleven (11) there are three prohibitions regarding social interaction with our fellow Muslims. These are (i) Mocking someone (ii) Defamation of character (iii) Calling people by offensive nicknames they do not like. Almighty Allah says in the Glorious Qur'an;

Mocking does not only imply mocking with the tongue but it also includes mimicking somebody, making pointed references to him, laughing at his words, or his works, or his appearance, or his dress, or calling the people's attention to some defect or blemish in him so that others also may laugh at him not only on social media but on a general term. All this is incorporated in mocking. What is actually prohibited is that one should make fun of and ridicule another, for under such ridiculing there always lie feelings of one's own superiority and the other's abasement and contempt, which are morally unworthy of a gentleman.
Moreover, it hurts the other person, which causes mischief to spread in society. Allah's command entails that a person should not be called by a name or a title which may cause him disgrace, e.g. calling someone a sinner or a hypocrite, Kafr (disbeliever) or calling somebody a lame or blind one, or one-eyed, or giving him a nickname containing a reference to some defect or blemish in him, or in his parents, or in his family, or calling a person a Jew or a Christian even after his conversion to Islam, or giving such a nickname to a person, or a family, or a community, or a group, which may bring condemnation or disgrace on it.

O you who have believed, let not a people ridicule (another) people; perhaps they may be better than them; nor let women ridicule (other) women; perhaps they may be better than them. And do not insult one another and do not call each other by (offensive) nicknames. Wretched is the name (i.e., mention) of disobedience after (one's) faith. And whoever does not repent - then it is those who are the wrongdoers (Qur'an, Surah Al-Hujuraat 49: Verse 11).

Mockery has become such a part of life these days! Allah emphatically prohibits it. We are asked to remember that perhaps those whom we mock might actually be better than us. This is a reminder to us to use good language as well. More often than not, mockery involves use of foul language (Raiiq Ridwan, n.d). 
In an in-depth interview (IDI) session with Usman Shehu, (a civil servant) who stated that today on social media, it is very rampant among young Muslims where comments on contents shared or forwarded become an avenue for mocking one another. This usually happens when someone posted, shared or forwarded a content where mistake is made either in the spelling or the information do not favour the other person, then they began to mock the person at the comment section of either Facebook or Twitter. This is against the statement of Allah which He says "Let not a group scoff at another group" in the above verse. There is no place in Islam for mocking, and there is no place in Islam for looking down upon someone. This is because the one you mock may be better than you in the sight of Allah as stated by Allah in verse 11 of Surah Al-Hujuraat.

An observation by the researchers on Facebook shows how Muslims defame and call each other by offensive nicknames. People's reputations and integrity are being defamed and their character assassinated for reasons that can be resolved in a civilized and matured way outside the social media.

According to Ja'afar Askilu, he said postings and sharing of contents on social media are flows of consciousness that go unnoticed. Where a post is defamatory, the damage done by a social media posting can be significant, and within a social group a reputation can easily be destroyed. He further asserted that lots of people's image, integrity, and reputation are defamed on social media by either Photoshop depicting them doing something unholy only to tarnish their image and reputation in the society. Today on social media people deliberately cook and share untrue or unkind statement, like accusing someone of abusing his or her spouse or children, such a statement or images would likely be considered defamatory.

It is evil to call a believer by nickname they do not like. Commonly, at the comment section on social media, Muslims are fond of attacking one another on matters that can be resolved in a matured way. But they end up calling each other by offensive nicknames. A Muslim calling his fellow Muslim brother (idiot, stupid, kafr, mushrik or Wahabi) just because of difference in terms of religious ideology which needs to be debated amicably. Allah says in Surah Al-Ahzaab,

Call them by [the names of] their fathers; it is more just in the sight of Allah. But if you do not know their fathers then they are (still) your brothers in religion and those entrusted to you. And there is no blame upon you for that in which you have erred but (only for) what your hearts intended. And ever is Allah Forgiving and Merciful (Qur'an, Surah Al-Ahzaab 33: $5)$.

Almighty Allah also says;

And those who harm believing men and believing women for (something) other than what they have earned have certainly born upon themselves a slander and manifest sin (Qur'an, Surah Al-Ahzaab 33: 58). 


\section{Verse 12: Prohibition of Suspicion}

In verse twelve (12) of the Surah Allah commands the believers to stay away from suspicion. Many a-times we are full of suspicion. Almighty Allah says that some kinds of suspicion are sinful. Obviously, if someone is hearing something or seeing something from someone who is known for deception, then it is ok to be suspicious. But a-times we are suspicious of everyone. Shaykh Bin Baaz says about it, "What is prescribed for the believer is to respect his brother, if he offers an excuse to him, to accept his apology if possible, and to think positively of him as much as possible, striving to keep hearts free of resentment and aiming to bring about unity and cooperation in doing good (Majmoo' Fatawa Ibn Baz). It was narrated from 'Umar (may Allah be pleased with him) in Majmoo' Fatawa Ibn Baz that;

Do not think badly of any word uttered by your brother when you can find a good interpretation for it (Majmoo' Fatawa Ibn Baz 26/365).

O you who have believed, avoid much (negative) assumption. Indeed, some assumption is $\sin$. And do not spy or backbite each other. Would one of you like to eat the flesh of his brother when dead? You would detest it. And fear Allah; indeed, Allah is Accepting of repentance and Merciful (Qur'an, Surah Al-Hujuraat 49: Verse 12).

Islam is against intruding into people's privacy, not only into their private apartments, but this also includes our dealings on social media. Muslims trying to dictate or spy into other people affairs with the intention of getting their faults and spreading same either on Facebook, WhatsApp, Twitter and other social media platforms. It has been observed by the researchers that, some Muslims online are of the habits of intruding other people's profile either on Facebook, Instagram, Twitter etc. with the aim of downloading their pictures or make screenshots of their messages and share same on social media without the prior permission of the owner or with the intention of exposing their secret to the world. Prophet Muhammad (Sallallahu Alayhi Wasallam) says in a Hadith,

It was narrated by Hudhaifah (may Allah be pleased with him) said I heard the Prophet (Sallallahu Alayhi Wasallam) saying "A Qattat will not enter Paradise (Sahih AlBukhari, Vol. 8, Hadith No. 82).

A Qattat is a person who conveys disagreeable, false information from one person to another with the intention of causing harm and enmity between them. It is haram to look into someone's private conversation, to go into their browser history and to go into their private photo collection on social media without their permission. One has no right to find out peoples secret and to expose it to the world. Islam is against thinking bad about a fellow Muslim, this is because it is the worst type of lies. Many Muslims are of the habit of that on social media. This is when two Muslims are either on Facebook, WhatsApp, or Twitter they began to think 
the worst between them not minding if he/ she are spouses (husband and wife). According to Ishaq Shuaibu Agafi, who relates that, there was an instance where a lady was posting comments on someone's post on Facebook and another brother opined that they are involved in something haram (prohibited), the brother told Agafi to investigate and when he did, Agafi found out that the person she was commenting on his posts on social media was her husband. That is why Prophet Muhammad (Sallallahu Alayhi Wasallam) says in a Hadith narrated by Abu Hurairah (may Allah be pleased with him) that Allah's Messenger (Sallallahu Alayhi Wasallam) says;

\begin{abstract}
Beware of suspicion, for suspicion is the worst of false; and do not look for other's faults, and do not spy on one another, and do not practice Najsh, and do not be jealous of one another and do not hate one another, and do not desert (stop talking to) one another. And O Allah's worshippers! Be brother (Sahih Al-Bukhari, Vol. 8, Hadith No. 92).
\end{abstract}

Muslims must respect the privacy of other people and avoid investigating or getting to the secrets of other people. This is because "what goes around comes around". When you go around looking for the secrets of people and exposing it Allah will make sure the same thing happens to that person.

Whoever conceals the faults of his Muslim brother, Allah will conceal his faults on the Day of Resurrection. And whoever exposes the faults of his Muslim brother, Allah will expose his faults even by revealing those he committed in (the privacy of) his home (Ibn Mājah No. 2546)

It was also narrated in a Hadith by Ibn Abbas (may Allah be pleased with him) that;

Narrated ibn Abbas (may Allah be pleased with him) Allah's Messenger (Sallallahu Alayhi Wasallam) passed by two graves and said, "Both of them (persons in the grave) are tortured, and they are not being tortured for a major sin. This one used not to save himself from being soiled with his urine and the other used to go about with columnies (among the people to rouse hostilities, e.g., one goes to a person and tells him that so-and-so says about him such and such evil things). The Prophet (Sallallahu Alayhi Wasallam) then asked for a green branch of a datepalm tree, split it into two pieces and planted one on each grave and said, "It is hoped that their punishment may be abated till those two pieces of the branch get dried (Sahih Al-Bukhari, Vol. 8, Hadith No. 78).

It is similarly a religious duty bound on every Muslim to protect the integrity, property, life, well-being and privacy of his fellow human beings except where Shari'ah has provided otherwise. It is part of the good virtue of Islam for a Muslim to 
keep off anything which does not concern/involve him (Ar ba'una Nabawi: Hadith No. 12). Muslims have also been admonished that whenever tidings are brought to them, they should verify and establish the truth so that regrets would be avoided. They should not also pitch a folk against another, not to defame or insult one another by nicknames and to shun suspicion, spying and backbiting one another; the Prophet Muhammad (Sallallahu Alayhi Wasallam) has also warned Muslims to desist from suspicion, looking for others' faults, spying, jealousy and hatred as stated in verses 11-12 above.

Sahihul Bukhari, Vol. 8, Hadith No. 90-93 and 99). All the above reflect direct regulation on the use of any means of communication and socialisation long time ago, before the development of modern information and communication technology which begot the social media.

\section{Verse 13: Tribalism and Racism}

The next and the last verse in our discussion, is verse thirteen (13), which is against racism and tribalism. Islam is against racism, tribalism and nationalism and has also warned Muslims against that. The Prophet (Sallallahu Alayhi Wasallam) also informed Muslims on the danger of tribalism and its resultant effects.

O mankind, indeed We have created you from male and female and made you peoples and tribes that you may know one another. Indeed, the most noble of you in the sight of Allah is the most righteous of you. Indeed, Allah is Knowing and Acquainted
(Qur'an, Surah Al-Hujuraat 49: Verse 13).

The influence of social media in fostering racism and hate among many Muslims around the world is unparallel. What is most unfortunate about this is the fact that most of the unfair comments online were triggered by racist news, feature stories and cartoons on social media. According to Ishaq Shuaibu Agafi, who states that many Muslims who pretend not to be racist in public, yet resort to making racist statements and comments online. A good example of such is that there are a lot of comments on Facebook by the youths which promote racism. Prophet Muhammad (Sallallahu Alayhi Wasallam) in a Hadith says;

He is not one of us who calls to tribalism. He is not one of us who fights for the sake of tribalism. He is not one of us who dies following the way of tribalism (Sunan Abi Dāwūd 5121).

But today individuals mostly engage in racism on social media in order to hurt others, and to confirm their racist views by connecting with like-minded people. Their preferred communication channels tend to be blogs, forums, news fields and chat rooms. Collective social media racism has the main effect of undermining the social cohesion of modern multicultural societies. It creates disunion, distrust and intergroup conflict. Meanwhile, individual social media racism appears to have a more direct effect by negatively affecting the wellbeing of the target individuals. It also contributes to maintaining a hostile racial/ tribal climate, which may (indirectly) affect the happiness of target group(s). Muslims 
need to be careful as regards the teachings of verse 13 of Surah Al-Hujuraat so as to avoid the promotion of racism and tribalistic contents on social media.

The life of Muslims is entirely a trial as Almighty Allah has created mankind, afford humanity with the capability to hear and know, and has shown mankind the righteous pathway in order to test them whether they would be appreciative to their maker or go astray; mankind has equally been informed and warned that they are in a state of loss except those who do good work and urge others to forfeit the world and its contents for obedience to Allah; (The Glorious Qur'an, Surah Insaan 76: 23 and Surah An-Nisaa 4:1).

Indeed, We created man from a sperm-drop mixture that We may try him; and We made him hearing and seeing.

Indeed, We guided him to the way, be he grateful or be he ungrateful (Qur'an, Surah AlInsaan 76: 2-3).

Almighty Allah also says,

O mankind, fear your Lord, who created you from one soul and created from it its mate and dispersed from both of them many men and women. And fear Allah, through whom you ask one another, and the wombs. Indeed, Allah is ever, over you, an Observer (Qur'an, Surah An-Nisaa 4:1).

\section{CONCLUSION}

In conclusion, this paper suggests that it is very important for Muslims to reflect on the teachings of Glorious Qur'an in our various homes and apply it in all of our social dealings which also includes the activities on the social media. Social media as a tool is very vital for the Muslims to exploit and make use of it, but it should be used in accordance with the teachings laid down by Islam. With the application of the teachings Glorious Qur'an in our usage of various social media platforms, Muslims will be able to avoid the evils that are associated with it and also guide one on the proper way of using most of the social media applications, be it Facebook, WhatsApp, YouTube, Twitter, Instagram etc. The connection between Islam and the social media world is not a new one, and cannot be over emphasized in view of the fact that while the former shapes the latter, the latter helps to disseminate and better express the message of Islam. In modern times, however, it has been refined, and permeated new spaces with a procedure that has greatly affected not only the flow of ideas and information, but also the modes of social interaction within and among socio-religious communities of the world.

\section{REFERENCES}

Abu Sulayman Muhammad, (2016). Social Media and Islam in the Contemporary Age. South Asian Research Journal of Humanities and Social Science, Vol. 6, Issue2.

Al-Hilali, M.T., and Khan, M.M., (2006). Translation of the Meanings of the Noble Qur'an in

English Language. Madinah, K.S.A: King Fard Complex for the Printing of the Holy Qur'an. 
Muhammad Maga Sule and Atiku Garba Yahaya

Al-Imam Abu Zakariya Yahya bin Sharaf An-Nawawi, (1999). English Translation of Riyad Us-Salihin (The Garden of the Righteous), with Commentary by Hafiz Salahuddin Yisuf. Riyadh, DarUs-Salam Publications.

Baran, S. (2013). Introduction to Mass Communication: Media Literacy and Culture. USA: The McGrawHills Company.

Cheong P., (2015). Religion and social media: got web?. Media Development [serial online]. February 2011; 58(1):23-26. Available from: Communication \& Mass Media Complete, Ipswich, MA.

Eastin, M. S (2013). (Ed). Encyclopaedia of media violence. California: SAGE Publications, Inc.

Hafiz Abu Tahir Zubair Ali Za'I, (2008). English Translation of Sunan Abu Dawud by Imam Hafiz Abu Dawud Sulaiman bin Ash'ath. Riyadh, Dar-Us-Salam Publications.

Halverson, J. R. \& Way, A. K (2012). The Curious case of Colleen La Rose: Social Margins, New Media, and Online Radicalization. Media, War \& Conflict, 5 (2).

Hammond, A.S. (1997). The Telecommunications act of 1996: Codifying the Digital Divide. Federal Communications Law Journal, 50 (1).

Harvey, K. (ed.). (2014). Encyclopedia of Social Media and Politics. Vol. I. Los Angeles: SAGE Publications, Inc.
Hawe, P. \& Shiell, A. (2000). Social capital and health promotion: A review, Social Science Medicine, 51 (6).

Hindman, D.B. (2000). The Ruralurban Digital Divide. Journalism and Mass Quarterly, 77 (3).

Javeria, Salman. (2011). "Impact of Media and Social Media on Islam and Muslims" The Message International Magazine. http://messageinternational.org/im pact-of-media-and-social-mediaon-islam-and-muslims/.

Moten, A. pure and practical ideology: The thought of Maulana Maududi (1903-1979). Islamic

Muhammad Muhsin Khan, (1997). The Translation of the Meaning of Sahih Al-Bukhari (ArabicEnglish). Riyadh: Dar-Us-Salam Publications.

Mujib Y., (2014). Islam and Social Media: The Involvement of Muslim Youths in Online Social Vices. International Journal of Arts, Humanities and Social Sciences Research, Vol. 8, Issue 3.

Nasiruddin al-Khattab, (2007). English Translation of Sahih Muslim by Imam Abul Hussain Muslim bin Al-Hajjaj, Volume 1, Riyadh: Maktaba Dar-us-Salam.

Parckard, A. (2013). Digital Media. Sussex - UK: John Wiley \& Sons, Inc.

Perritt, H. H. (1996). Law and the Information Superhighway. New York: John Wiley \& Sons. SAGE Publications, Inc. 
Conceptualizing The Principles Of Social...hal.1-18

Raiiq Ridwan (n.d). 5 Negative Character Traits (from Surah Hujurat) https://understandquran.com/5negative-character-traits-fromsurah-hujurat-cc.

Sheikh Abdul' Aziz Bin Abdullah Ibn AbdulRahman Ibn Bazz, English Translation of Majmoo' Fatawa.

Smith, G. J. H. \& Bird, B. (2002). Internet Law and Regulation. London: Sweet and Maxwell.

Social Media and Conflict, (http://ploughshares.ca.pl_publica tions/social-media-and-conflict/. Accessed on 10/10/2019.

Theocharis, Y. (2011). Young People, Political Participation and Online Post Materialism in Greece. New Media \& Society,

Van Zoonen, L., Vis, F., \& Mihelj, S. (2011). YouTube Interactions between Agonism, Antagonism and Dialogue: Video Responses to the Anti-Islam Film Fitna. New Media \& Society, 13 (8).

Veenstra, G. (2000). Social Capital, SES and Health: An Individual-level Analyses. Social Science and Medicine, 50 (5).

Zakir, Naik. (2016). Muslims must use Social Media for Dawah. http://zakirnaikfansofficial.blogspot.com/ 2016/04/muslims-must-use-socialmedia-for-dawah.html?m=1.

\section{List of Informants}

Ja'afar Askilu, (30 Years), Postgraduate Student, Federal University of Lafia, interviewed in Nasarawa
State, Nigeria, Lafia, on 09/12/2019.

Ishaq Shuaibu Agafi (40 Years), Civil Servant, Nasarawa State Universal Basic Education Board, interviewed in Nassarawa Eggon, Nasarawa State, Nigeria, on $11 / 12 / 2019$.

Usman Shehu, (47 Years), Civil Servant, Niger State Judiciary, Minna, interviewed in Minna, Niger State, Nigeria, on 13/12/2019.

West, Richard and Lynn H.G.Turner, Introducing Comunication Theory: Analysis and Aplication, New York: McGraw Hill, 2012. 